This is the post print version of the article, which has been published in The International Review of Retail, Distribution and Consumer Research. 2017, 27 (3), 284-299.

http://dx.doi.org/10.1080/09593969.2017.1314863.

This document has been downloaded from TamPub uta.fi The Insitutional Repository of University of Tampere

\title{
Uncovering Consumers' Returning Behaviour: A Study of Fashion E-commerce
}

\author{
Authors: Hannu Saarijärvi, Ulla-Maija Sutinen and Lloyd C. Harris
}

\begin{abstract}
The increasing prominence of e-commerce is shaping the nature and dynamics of retailing. E-commerce offers consumers lower prices, wider product categories and a more convenient shopping experience. In addition, consumers seek ways to manage the risk that is often perceived when making purchases online, which is why retailers' online return policies have become an increasingly important attribute through which companies compete. Lenient return policies fuel unnecessary ordering and increases return rates, which in turn has major implications both for consumer behaviour and for managing the increasingly complex ecological and economical issue of online returning. Despite its relevance, prior research has paid limited attention to this evolving phenomenon. Consequently, the purpose of this study is to explore and analyse online returning behaviour in the context of fashion merchandise. As a result, ten categories of online returning behaviour are identified that capture the reasons why consumers actually return items they have ordered online. These categories are further linked with when the decision to return ordered items emerges. Based on the results, managerial implications are provided to give guidance in managing online returning behaviour.
\end{abstract}

Keywords: online returning behaviour, e-commerce, retailing, fashion retailing, return policy

\section{Introduction}

In comparison with traditional brick-and-mortar retailers, e-commerce offers consumers lower prices, wider product categories and a more convenient shopping experience. In parallel with this evolution, retailers' online return policies have become an increasingly important and additional element through which companies compete. Consumers do not merely compare product ranges or prices, but also evaluate retailers' product return policies and process. Consequently, many leading online retailers - such as Zalando, Zappos, and Asos - have accommodated free product return policies as an important part of their overall service offering. 
The trend towards more liberalized return policies in e-commerce (Hjort et al. 2013) has significant implications for how consumers search, compare, order and buy products online. Free return policies lower consumers' perceived risk of purchasing online, which on the one hand drives sales, but on the other hand may fuel frivolous product orders: online returning behaviour is evolving forms that go beyond conventional returning, such as merely returning defective products. Recent reports estimate that online returns that are due to consumers' opportunistic behaviour have increased by $20 \%$ (The Retail Equation 2014), which characterizes the dark side of e-commerce (see The Economist 2013; Minnema et al. 2016). This has become a major challenge for e-commerce players, both large and small, and especially for those who are operating in fashion merchandise. For example, it is estimated that $50 \%$ of the major German-based online retailer Zalando's fashion merchandise is being returned (Zalando 2014; Thomasson 2014). A recent study published in Harvard Business Review also indicated that product returns are an increasingly costly challenge for retailers (Minnema et al. 2016). It is only by better understanding the variety of online returning behaviours that companies can develop the means to manage the diverse impacts of unnecessary product ordering.

The aim of this study is to explore and analyse online returning behaviour in the context of fashion merchandise. Being a relatively new research area, very little is known about online returning, even though the issue is both timely and relevant from managerial and theoretical perspectives. This study aims to contribute to this area of research by exploring online returning in fashion e-commerce context from the consumers' perspective. We identify the different reasons why fashion merchandise is returned, link these reasons with when the decision to return ordered merchandise is made and build categories that group similar returning reasons into larger entities. We begin by first briefly reviewing the existing literature on returning behaviour. The focus of the theory chapter is not to provide a thorough literature review on returning behaviour, but to introduce the basic concepts that are related to this research phenomenon such as perceived risk, the role of return policies in driving return behaviour and latest research findings. Second, we report the methodology used to address the study's purpose, after which the different reasons for returning are identified, linked with the phases of the online buying process and grouped into larger categories of online returning behaviour. We conclude with a discussion of our 
contributions and conclusion and outline the study's limitations and future research directions.

As a result, we hope to contribute to existing research by providing a deeper and more diverse understanding of consumers' online returning behaviour and thus extending contemporary conceptualization of returning behaviour. Furthermore, the study provides a well-grounded basis for future research on modelling the linkages between different types of returning behaviour, behavioural antecedents and key outcomes, such as satisfaction, loyalty and word of mouth. Finally, the study will provide implications for retailers to manage the increasing return rates that fundamentally characterize contemporary ecommerce.

\section{Theoretical framework}

\section{Return policies and perceived risk}

In the online environment, purchase uncertainty and risk are more obvious, as consumers lack the opportunity to physically test and experience the products, though recent digital developments and peer review sites increasingly aim at reducing this risk. Offering consumers lenient return policies is yet another way to manage consumers' purchase uncertainty: return policies can be regarded as consumer risk relievers to increase consumer demand (Janakiraman, Syrdal, and Freling 2016). Although increasing return rates are on the one hand problematic for both offline and online retailers, on the other hand, recent studies show that they are also means to increase both short- and long-term profits (Petersen and Kumar 2015). Retailers can gain substantial advantages from free returns (Bower and Maxham 2012). According to Janakiraman, Syrdal, and Freling (2016), overall leniency in a company's return policy increases purchases more than it does returns. Similarly, Griffis et al. (2012) showed that in the online retailing environment faster return processes are correlated with customer retention, increased purchase frequency and purchase amount. They also noted that customers are sensitive to the speed of the refund process; informing customers when they are to be refunded is a practical way to increase loyalty. Moreover, Pei, Paswan, and Yan (2014) have found that return depth, i.e. full or partial return policy - the degree to which consumers are allowed to return items free of charge, positively influences consumers' perceived return policy fairness, trust, and 
purchase intention. Moderating effects of perceived competition and online retailer's reputation were also identified.

Return policies can thus be regarded today as a critically important characteristic of the overall online retailing offering: they can be used to communicate quality, and some consumers may interpret lenient return policies as such a signal (Bonifield, Cole, and Schultz 2010). Therefore, return policies can be seen as an increasingly important strategic decision that usually varies in terms of monetary leniency, time leniency, effort leniency, scope leniency and exchange leniency (Janakiraman, Syrdal, and Freling 2016). Also Hjort and Lantz (2016) encourage retailers to be very careful while making choices about product leniency factors, the levels of leniency, and usage of such leniency factors, since these decisions may have significant consequences.

\section{Returning behaviour}

Lenient return policies fuel unnecessary ordering-thereby resulting in opportunistic buying behaviour and excessive return rates. Studies conducted in offline retailing settings suggest that returning behaviour can in fact take diverse forms, i.e. the reasons why consumers actually return products differ considerably. Foscht et al. (2013) analysed the returning behaviour of mail order buyers and classified the returners based on their returning frequency into four groups: heavy returners, medium returners, light returners and occasional returners. These groups did not differ only in the extent to which return policies were used, but also in terms of their initial motivation for shopping and their spending patterns.

Similarly, Wachter et al. (2012) identified three dimensions that are relevant for consumer return behaviour: the planned or unethical returner (customers who intentionally plan unethical returns), the eager returner (customers who see returning as a good decision and feel good when they complete a return) and the reluctant or educated returner (customers who find returning embarrassing or feel guilty about it). Previous studies have also identified demographics (e.g. gender, age, income) that explain return behaviour (Harris 2008; Harris 2010). King and Dennis (2006) have explored factors that can be linked with returning behaviour, such as the timing when returning the already bought items back to the store (e.g. just before the closing time), to whom to return the items (e.g. 
junior members of the staff) or earlier return behaviour (e.g. how the past return processes have succeeded).

Consequently, while some consumers may have justified reasons for returning items they have bought or ordered, other consumers may take advantage of a free return policy (see Wachter et al. 2012). This phenomenon is labelled as 'fraudulent returning', and can be defined as 'the returning of a product broken by the customer after purchase or the returning of a non-faulty product after it had been used' (Harris 2010, 734). One form of such behaviour has been identified and analysed by Hjort and Lantz (2012), who concluded that a fraudulent consumer phenomenon, i.e. retail borrowing behaviour, exists in fashion e-commerce. They also found that return leniency seems to reinforce such behaviour.

Altogether, it can be argued that online retailers compete increasingly through lenient return policies in their quest for enhanced market position and increased volume. As a result, consumers' return behaviour is taking diverse forms. Some return behaviour is unplanned, e.g. consumers just not being satisfied with how the product looks, but some is planned, i.e. when the decision to return is made already before ordering the products and can in fact take also unethical characteristics (see Wachter et al. 2012). Hence, from the retailer's point of view, the time when the decision to return is made is of critical importance, as it would help retailers manage the possible return process in advance, for example, through well-timed provision of information.

In addition, the return process can be triggered due to consumers' actions, as discussed above, or retailers' actions. When exploring online returning behaviour, the question whether the reasons to return are first and foremost due to the consumer or the retailer provides complementary insight about this evolving phenomenon.

Powers and Jack (2013) observed that retailers should focus more on identifying ways how to manage returning behaviour. While retailers cannot directly influence the opportunistic nature of customers, they could identify and isolate specific segments that are more opportunistic in their returning behaviour by analysing returns and the types of customers that make them. Hjort et al. (2013) also concluded that retailers must segment their customers on the basis of their returning behaviour (see also Foscht et al. 2013). However, this necessitates a better understanding of why and when consumers decide to 
return. This insight would also help retailers to create competitive advantage through a differentiated return service. By offering differentiated return services, retailers could both attract new customers and better support the existing customer groups that have diverging purchasing and returning patterns (Hjort et al. 2016).

\section{Methodology}

Given the nature of both the study purpose and the evolving research phenomenon, the focus of this study is on exploring returning behaviour rather than explaining its causal linkages. As online returning behaviour can be considered a relatively new and stillevolving phenomenon, and as such returns may also be opportunistic, it was deemed important to assess how to approach the research phenomenon. At this phase of empirical inquiries addressing online returning behaviour, using traditional surveys might not result in adequate empirical access to study different forms of online returning behaviour. Consequently, a qualitative and interpretative approach was deemed appropriate.

\section{Data generation}

A set of 21 semi-structured interviews were conducted to gain insight into the diversity of returning behaviour in an online fashion merchandise context. The interviewees were contacted by using multiple approaches, including the purposive method, searching for volunteers in university courses and through the authors' own networks. Prior to selecting the informants, the interviewees were expected to have adequate experience of buying fashion items online (at least four purchases during the past 12 months).

The interviews followed a pre-designed set of questions, but the overall aim was to allow the respondents to speak freely about their online buying behaviour in general and their returning behaviour in particular. This included, for example, encouraging the informants to describe in their own words specific online buying processes that resulted in returning the items. Emphasis was not placed on the attributes of the purchase as such (e.g. the online store, brand price, delivery, or other non-monetary costs), but the overarching focus was on uncovering and identifying the various ways of and reasons for returning fashion items. This interview design resulted in lively, informative and rich discussion of the nature and types of online returning. All the interviewees considered themselves experienced online buyers. The interviews were recorded and transcribed and pseudonyms were used. The 
lengths of the interviews varied between 25 and 62 minutes. The majority $(86 \%)$ of the respondents were female, which can be explained by the research context of fashion merchandise. The median age was 26 years. After 16 interviews, the data started to saturate as certain themes started to recur. After this, 5 additional interviews were conducted to ensure that all aspects relevant to the research purpose were covered, and since no significant new insights emerged, the amount of data was deemed sufficient.

\section{Data analysis}

Given the purpose of the study, i.e. exploring and analysing online returning behaviour in the context of fashion merchandise, the data analysis focused on empirical themes that emerged from the data. In more detail, the process consisted of three complementary phases. First, all the transcriptions were read several times in order to get an overall picture of the content of the interviews. During this phase, initial notes and tentative ideas of possible forms of online returning behaviour were written down. Second, a more indepth exploration of the interviews was done in order to achieve a more thorough understanding of the diversity of returning behaviour. This included the identification of all the different reasons for online returning behaviour. The overarching question that drove the analysis here was related to the very reason why interviewees decided to return the item(s). In addition, focus was placed on uncovering when the decision to return the items started to emerge. This first resulted in identifying 22 different reasons for returns (e.g. wrong colour, misleading product information, not good fit).

When further analysing these different reasons, the researchers soon realized that the decision to return due to these reasons varied considerably in terms of when the decision was made. Consequently, at the third phase of the analysis, the identified reasons for online returning behaviour were grouped into distinct phases on the basis of when consumers made the decision to return the ordered merchandise. Here, the analytical focus was on identifying the complementary joints of the buying process, i.e. exploring online buying behaviour from the chronological point of view. The results are presented and discussed in the following section.

\section{Results}


The data analysis process resulted in identifying the different phases during which decisions to return occurred and the specific reasons for returning (Table 1). Altogether 6 phases were identified: searching and ordering (searching and ordering fashion items online), delivery (the items being delivered), arrival (the items arriving at home or at the post office etc.), seeing, touching and feeling (viewing the items for the first time), experimenting (trying the items on) and usage (using the items). These phases and the respective reasons for returning are addressed in more detail below.

"Take in Table 1 here"

\section{Identifying the phases of and reasons for returning behaviour}

\section{Phase 1: Searching and ordering}

The first phase of buying fashion merchandise online was characterized by consumers searching and ordering fashion merchandise in a variety of ways online. In addition to aiming at finding the most suitable products for their needs, consumers longed for inspiration; many interviewees talked about how they were searching for ideas and something exciting to order. To achieve this, they utilized retailers' wide selection and lenient return policies, and consequently, ordered items even without any intention to keep them. Thus, some consumers already made the decision to return at this phase, for example, because they wanted to maximize the likelihood of getting the right-sized products. The following interview excerpts illustrate this point:

I mean if the model seems at all to be a so-called slim fit model, then I usually get it in two different sizes because there's always the risk that the smaller slim fit garment won't fit me. (Megan, unemployed, 35)

l've ordered two different sizes straight away when I didn't know for sure and then thought about it, but I haven't known whether they fit my body or how they look on me in the end, you know. I've ordered quite randomly many times, and every time one or the other piece-or all of them-has always been returned. (Sarah, sales assistant, 26) 
In some cases, informants told that they had ordered many different products for the same need. For example, they ordered a number of different brands or models to find the right one for a specific party.

Like, for example, last summer I ordered several party dresses, like several different models, so I knew I was only going to keep one of them ... so if any one of them would fit, I would keep that one and then return the rest. (Elizabeth, sales assistant, 28)

Here, the intention was to keep only one item; the decision to return was made prior to ordering the products.

In addition, some consumers order fashion items just for the sake of trying them out at home. In these cases, there was no intention to keep the product(s). Instead, the focus was on getting an opportunity to try on the shoes or skirts that he/she found interesting, but for some reason, impossible to buy at the time. For example, the interviewee might have been short on money, or he/she knew a place where to get the product cheaper, but wanted to order the product anyway for fitting.

\footnotetext{
They [shoes] were quite expensive, so for that reason too I didn't want to just directly order and keep them ... when they arrived at [Name of an online store], I went there to see every now and then whether they had arrived, and then they turned up there and then I ordered them ... I tried them on and I got to check them out at home, like how they feel and what my size would be. I ordered them and they were good, but then I thought that l'll have more use for them in the summer and a little more money, or some extra money, so I'll order them in the summer through the [Other country] online store. (Cristopher, student, 24)
}

In all cases, returning behaviour was planned in advance: the decision to return the items was done prior to the order.

\section{Phase 2: Delivery}

Consumers' decisions to return also emerged after ordering the merchandise but prior to their arrival. This phase was characterized by consumers finding the ordered products cheaper or faster from another retailer while waiting for the products to be delivered. For example, consumers received additional discount coupons for another online retailer or 
even found the exact same items from a physical store with a fair price and wanted to have it right away.

\begin{abstract}
If there's a product, usually it's something l've been checking out for a long time, some specific piece of clothing or some other item or whatever. So l've ordered it, but then I've noticed that it's cheaper someplace else, so I may have, if it's real easy to make a return and so on, so l've returned it and then got it from that other place instead. (Ashley, claims handler, 23)
\end{abstract}

In these cases, consumers wanted to return the items and get refunded as soon as possible, since they had also purchased the items from another place. After ordering the products, some consumers also realized that they could not really afford the items. Consumers reconsidered their ability to pay for all the ordered products. For example, they might have ordered too many products or products that were too expensive, and after ordering the products began to regret doing so and thus never collected the merchandise from the post office.

Well, actually there have been occasions that I've regretted when l've ordered a whole bunch of stuff...several hundreds of euros worth, and then I've realized that maybe I don't need all of that and then I actually never even collected it. (Michael, sales team leader, 24)

Here, the decision to return the ordered items emerged either after ordering the products or after receiving the products, as the amount of ordered items became more concrete and perceivable. In some cases, customers already knew when ordering the products that they were going to return many of the items due to a shortage of money. The customer wanted to try the clothes and then decide which ones he/she could afford to keep.

\title{
Phase 3: Arrival
}

The arrival of the merchandise refers to the phase when the ordered items were delivered to the consumers, but before the consumer has seen, touched or felt them. The merchandise was delivered to the customer's home or the post office, but the package remained unopened. At this phase, some consumers realized that they did not want or need the ordered merchandise, i.e. the purchase was to a large extent impulsive; the consumer's original need or want had faded away by the time of the delivery. 
But then it also depends a little bit on the fact that usually if I buy several things, I also buy the sort of things that I haven't originally been planning to buy or that I was not specifically trying to find. But if I buy, like, one product only, then it's usually something l've been trying to find and it's exactly what I want and then I probably won't return it. But I guess if I order things other than what I originally had thought I'd buy, then it's probably only later on that I realize that this product is not that good after all and that I just felt the urge to buy it as I was browsing. (Stephanie, student, 25)

In some cases, the need faded away due to external reasons, for example, because the season was changing.

Once again I bought two pairs of shoes and returned them both. There were winter shoes, but then the winter was almost over and they weren't exactly what I was looking for, so I returned them.

(Cristopher, student, 24)

\section{Phase 4: Seeing, touching and feeling}

When consumers perceive the ordered merchandise for the first time, it is obviously a critically important phase in terms of whether or not the merchandise will be returned. Consumers' opportunity to assess the extent to which the ordered items meet the expectations characterizes this phase of the buying process. Consequently, reclamations were an obvious reason for returns at this phase. Reclamations were due to the retailer delivering items that had quality problems, which is why consumers wanted to return them and either be refunded or reorder the same merchandise. For example, a skirt might have had bad sewing or a colour defect.

Reclamations and refunds could also be due to the retailer's erroneous order fulfilment processes. In these cases, the main reason for returning the products was the fact that the wrong products had been delivered to the customers. Thus, returning was not due to product defects as such, but to receiving the wrong products. The decision to return the item emerged after receiving the products and perceiving the apparent mistake in the order fulfilment.

In fact, quite often with this one online store it's because the size of the product they send is wrong. It's funny that if I order, for example, two pairs of shoes, one pair may be the right size but the other may be size 36, like someone would order a second pair that's two sizes larger... 
In addition, some interviewees explained their returns by telling that either the description or the picture of the product differed from what they actually received. In these cases the expectation did not match the reality. For example, the colour of the product was different compared to the one in the picture. Sometimes the fabric or the product itself looked better or somehow different in the picture. In a couple of examples the interviewees told that something essential was left out of the picture. One interviewee also mentioned that one of his returns was made because the description on the website was wrong.

In the summer I ordered through [Name of an online store] the [Name of the exclusive shopping club for members] thing. There was this, I wonder what it was, maybe a Lindeberg suit, so that it was 60$70 \%$ off, so I just thought that it looked good and so I'll order that one. And I ordered it and when it came ... in the image it looked like a regular suit, like, with a straight leg and such, but the hem of the leg was sort of serrated. I dunno whether I was supposed to sew it myself or what, what was the deal, but that's how they were, and then there was also something wrong with the sleeves of the jacket that you couldn't see in the image and that I really didn't expect, so that one went right back. (Matthew, student, 26)

There was this red dress that I wanted. It was a specific shade of red, and in the image it looked like this specific shade of red. We're talking about very subtle differences in shades here, but when I got it home it turned out to be a completely awful shade of red. No matter how [chuckles] positively I tried to look at it in the mirror, it didn't suit me in any way. I dunno what the problem was after all. (Alexis, claims advisor, 29)

\section{Phase 5: Experimenting}

Another important and distinct phase of the online buying process of fashion merchandise was when consumers tried on the ordered items. Here, a number of informants had faced problems with the different size charts retailers use. Despite the fact that consumers had ordered the same size they usually wore, the product was either too big or too small. This caused frustration and negative emotion, as customers needed to spend the time and effort to return and then reorder the products. Importantly, here customers had not ordered many sizes of the same product in order to manage the risk of ordering unfit items. Consequently, the decision to return items emerged after trying the items on.

Many informants also reported about cases when they had ordered products that they perceived as nice and that were also the right size, but while trying them on it somehow 
was just not their 'thing' or the item did not match his/her style. They did value the brand or quality, but there was something missing in order for them to decide to keep the product; the consumer's 'feeling' about the ordered merchandise was not right.

\footnotetext{
Well, usually the reason is that it wasn't how I thought it would be or it doesn't fit me or doesn't look good on me. (Nicole, planner, 32)

I had a vision in my head about how I wanna combine it with things or how it would fit me or the whole look, but then it wasn't what I had imagined in my head and so I returned it or I swapped it. (Sarah, sales assistant, 26)
}

Here, the decision to return matured while fitting the merchandise, which was not necessarily immediately after the first time the items were tried on, but gradually during the first couple of days after the product's arrival.

\section{Phase 6: Usage}

The usage of the merchandise refers to the final phase when consumers decided to start using the ordered items. However, in some cases, consumers also faced quality issues after using the product for a while:

Once I returned a pair of jeans after l'd already used them for a bit. After the first wash the colour or something went bad, but still the return went quite okay. (Elisabeth, sales assistant, 28)

Hence, quality defects are not limited to the perception phase, but could also be realized in the usage phase, thereby resulting in reclamations.

\section{Categories of online returning behaviour}

On the basis of the exploration of the reasons and timing of returning behaviour, the returning behaviour can be grouped further into larger categories (Table 2).

\section{"Take in Table 2 here"}

These categories differ in terms of what fundamentally drives returning behaviour, i.e. whether returning was due to the defects in the product (reclamation), wrong products 
being delivered (order fulfilment), finding better post-order deals (competition), an unexpected feature of the product (disconfirmation), the wrong size (size chart), the product just not feeling quite right (feeling), not having the money for the ordered items (money shortage), ordering multiple items in order to find a suitable one (benefit maximization) or ordering to try the product out before purchasing it in the future from another outlet (just trying out).

These categories can be further divided on the basis of whether online returning behaviour is planned or unplanned (compare with Wachter et al. 2012) and whether it is consumeror other-initiated. Hence, as is depicted in Table 3, the identified categories enrich the existing conceptualization of returning behaviour into planned and unplanned, and provide a more grounded basis to uncover the diversity of returning behaviour.

"Take in Table 3 here"

Furthermore, Figure 1 below summarizes the key findings of the study by combining the categories of returning behaviour with the phases when the decision to return is made. As a whole, the figure provides a good basis for further discussion.

'Take in Figure 1 here'

\section{Discussion}

Online returning behaviour takes diverse forms. Understanding and discussing their distinct characteristics provides important insight for scholars and practitioners. We will now discuss the three main findings that also characterize the contribution of the study.

First, this study develops a more complex and complete framework of online returning behaviour. It extends existing conceptualizations of returning and incorporates the idiosyncrasies of the online context. Existing frameworks address returning behaviour as planned or unplanned (e.g. Wachter et al. 2012). While this is an important notion per se, it classifies a hugely complex behaviour into a too simple conceptualization. This study 
provides a more grounded conceptualization by identifying both the different phases when the decision to return is made and the reasons why consumers choose to return items. Prior research has neglected addressing returning behaviour simultaneously through its two fundamental and complementary perspectives. We address this gap by integrating and illustrating these two perspectives and argue that investigating one without the other does not result in adequate understanding of the nature of the online returning behaviour.

Second, existing research is strongly based on exploring and analysing the linkage between perceived risks and returning behaviour (see Petersen and Kumar 2015; Foscht et al. 2013). However, on the basis of this study, online returning behaviour can take forms that go beyond consumers' purchase uncertainty: consumers order fashion items in order to try them on for fun or for possible future purchase, or excess products are ordered in order to avoid dispatching or other service fees. Moreover, lenient return policies combined with consumers' e-impulsive buying behaviour (see e.g. Park et al. 2012) or as a tool to experience alternative representations of self (see Belk 1988) can drive excess purchases. E-commerce players are increasingly learning how to utilize consumers' impulses and tap on "spur of the moment". Thus, online returning behaviour is a diverse and evolving phenomenon, and consumers are increasingly taking advantage of lenient return policies as if they are playing a game.

Third, this study has important conceptual and practical implications. Conceptually, it supports the view that while frameworks and theories from the offline context can generate insight into online issues, it is important to use them cautiously and to test their applicability. In this case, these approaches work to a limited degree, as e-commerce has unique characteristics in relation to bricks-and-mortar retailing, making it a more diverse context for returning behaviour. Gaining a deeper understanding of online returning behaviour also provides practitioners with better means to address the array of challenges resulting from returning behaviour.

\section{Conclusions}

The various forms of returning behaviour result from retailers increasingly competing through lenient return policies that lower perceived risk for online purchases and thus increase demand. The different categories of returning behaviour are partially due to the 
spillover effect of those policies. To address this increasingly important phenomenon, the purpose of this study was to explore and analyse online returning behaviour in the context of fashion merchandise. This study is among the first to explore the different forms of returning behaviour in an online context. More importantly, it extends research towards identifying the time when the decision to return is originally made. This is important for practitioners, as it informs them when to pursue strategies to avoid unnecessary ordering.

\section{Managerial implications}

Understanding the diversity in online returning behaviour is the key to managing it. Despite the fact that lenient return policies can be seen as a risk reliever for consumers that help to drive sales, online retailers should carefully identify ways to decrease such unnecessary returning behaviour. Here, understanding both the type of online returning behaviour and the time when the decisions to return are made provides the basis for managing online returning behaviour (Table 4).

\section{"Take in Table 4 here"}

Table 4 is compiled by using the insights that emerged from the interviews as a basis for exploring how eventually retailers could manage the diverse returning behaviour. The authors carefully considered each type of returning behaviour and identified possible actions that could be linked to decrease respective returning behaviour. Although the implications above are partly parallel and are not comprehensive, they provide insight into managing heterogeneous online returning behaviour. They offer guidance for retailers when designing alternative approaches to managing the increasing return rates. Moreover, retailers need to consider linking customer loyalty programs with customers' returning behaviour. This could provide incentives for consumers to decrease their return rates.

\section{Limitations and future research}

Given that the purpose of the study was explorative in nature, the study was built on a qualitative research setting. The aim was not to provide generalizable results, but to uncover what kind of returning behaviour underlies the increasing e-commerce return rates. It should also be noted that returning behaviour can be regarded as a difficult empirical arena that can suffer from inadequate data access: informants may not want to 
talk about behaviour that can be considered as opportunistic or unethical. Previous studies (e.g. Harris 2008, 2010) have reported findings that refer to fraudulent returning behaviour, e.g. returning items that the customers themselves broke or have already been used, though it was not reported in this study.

More empirical research is needed to deepen the understanding of this important and evolving research phenomenon. For example, modelling online returning behaviour could serve as a logical step forward in conceptualizing and quantifying the phenomenon. In addition, attention could be shifted to exploring the more opportunistic and fraudulent side of e-commerce returning behaviour, and exploring in-depth the role and potential of different logistical systems in handling the diverse returning behaviour. It would also be interesting for scholars and practitioners alike to gain empirical insight into how various managerial activities directed at minimizing the different forms of online returning behaviour actually affect consumers' excess ordering in the future. Furthermore, modelling the linkages between different types of returning behaviour, behavioural antecedents and key outcomes, such as satisfaction, loyalty and word of mouth, would provide complementary insight into online returning behaviour.

\section{References}

Belk, R. W. 1988. "Possessions and the extended self", Journal of Consumer Research 15 (2): 139-168.

Bonifield, C., C. Cole, and R. L. Schultz. 2010. "Product Returns on the Internet: A Case of Mixed Signals?" Journal of Business Research 63 (9): 1058-1065.

Bower, A. B., and J. G. Maxham III. 2012. "Return Shipping Policies of Online Retailers: Normative Assumptions and the Long-Term Consequences of Fee and Free Returns." Journal of Marketing 76 (5): 110-124.

Foscht, T., K. Ernstreiter, C. Maloles III, I. Sinha, and B. Swoboda. 2013. "Retaining or Returning? Some Insights for a Better Understanding of Return Behaviour." International Journal of Retail \& Distribution Management 41 (2): 113-134.

Griffis, S. E., S. Rao, T. J. Goldsby, and T. T. Niranjan. 2012. "The Customer Consequences of Returns in Online Retailing: An Empirical Analysis." Journal of Operations Management 30 (4): 282-294.

Harris, L. C. 2008. "Fraudulent Return Proclivity: An Empirical Analysis." Journal of Retailing 84 (4): 461-476. 
Harris, L. C. 2010. "Fraudulent Consumer Returns: Exploiting Retailers' Return Policies." European Journal of Marketing 44 (6): 730-747.

Hjort, K., and B. Lantz. 2012. "(R)e-Tail Borrowing of Party Dresses: An Experimental Study." International Journal of Retail \& Distribution Management 40 (12): 997-1012.

Hjort, K., and B. Lantz. 2016. "The Impact of Returns Policies on Profitability: A Fashion ECommerce Case." Journal of Business Research 69 (11): 4980-4985.

Hjort, K., B. Lantz, D. Ericsson, and J. Gattorna. 2013. "Customer Segmentation Based on Buying and Returning Behaviour." International Journal of Physical Distribution \& Logistics Management 43 (10): 852-865.

Hjort, K., B. Lantz, D. Ericsson, and J. Gattorna. (2016). Customer Segmentation Based on Buying and Returning Behaviour: Supporting Differentiated Service Delivery in Fashion E-Commerce. In Developments in Logistics and Supply Chain Management, edited by K. Pawar, H. Rogers, A. Potter, and M. Naim, 153-169. UK: Palgrave Macmillan.

Janakiraman, N., H. A. Syrdal, and R. Freling. 2016. "The Effect of Return Policy Leniency on Consumer Purchase and Return Decisions: A Meta-Analytic Review." Journal of Retailing 92 (2): 226-235.

King, T., and C. Dennis. 2006. "Unethical Consumers: Deshopping Behaviour Using the Qualitative Analysis of Theory of Planned Behaviour and Accompanied (De)Shopping." Qualitative Market Research: An International Journal 9 (3): 282-296.

Minnema, A., T. H. A. Bijmolt, S. Gensler, and T. Wiesel. 2016. "When Positive Product Reviews Backfire for Retailers". September 20. https://hbr.org/2016/09/when-positiveproduct-reviews-backfire-for-retailers.

Park, E. J., E. Y. Kim, V. M. Funches, and W. Foxx. 2012. "Apparel Product Attributes, Web Browsing, and E-Impulse Buying on Shopping Websites", Journal of Business Research 65 (11): 1583-1589.

Pei, Z, Paswan, A., and Yan, R. (2014). "E-tailer's Return Policy, Consumer's Perceptino of Return Policy Fairness and Purchase Intention." Journal of Retailing and Consumer Services 21 (3): 249-257.

Petersen, J. A., and V. Kumar. 2015. "Perceived Risk, Product Returns, and Optimal Resource Allocation: Evidence from a Field Experiment." Journal of Marketing Research 52 (2): 268-285.

Powers, T. L., and E. P. Jack. 2013. "The Influence of Cognitive Dissonance on Retail Product Returns.” Psychology \& Marketing 30 (8): 724-735.

The Economist. 2013. "Return to Santa." December 21.

http://www.economist.com/news/business/21591874-e-commerce-firms-have-hard-corecostly-impossible-please-customers-return-santa 
The Retail Equation. 2014. "Consumer Returns in the Retail Industry". Accessed March 13 2016.

http://www.theretailequation.com/Retailers/images/public/pdfs/industry_reports/ir_2014_nrf _retail_returns_survey.pdf

Thomasson, E. 2014. "Online Fashion Retailer Zalando Gets Makeover as Eyes Listing." Reuters, August 28. http://www.reuters.com/article/zalando-ipoidUSL5N0QY0SR20140828.

Wachter, K., S. J. Vitell, R. K. Shelton, and K. Park. 2012. "Exploring Consumer Orientation Toward Returns: Unethical Dimensions." Business Ethics: A European Review 21 (1): 115-128.

Zalando 2014. "Corporate Page: FAQ." Accessed May 152016.

https://corporate.zalando.com/en/ive-heard-lot-about-your-return-rates-how-high-are-theyreally 
Table 1. Phases of online buying process and related reasons for returning

\begin{tabular}{|c|c|}
\hline PHASE OF ONLINE BUYING PROCESS & REASONS FOR RETURNING \\
\hline \multirow{5}{*}{$\begin{array}{l}\text { SEARCHING AND ORDERING } \\
\text { Consumers search and order fashion } \\
\text { merchandise online }\end{array}$} & $\begin{array}{l}\text { Ordering many sizes of the same product with the intention to } \\
\text { keep only one }\end{array}$ \\
\hline & $\begin{array}{l}\text { Ordering the same product in many different colours with the } \\
\text { intention to keep only one }\end{array}$ \\
\hline & $\begin{array}{l}\text { Ordering alternative products for the same need with the } \\
\text { intention not to keep all of them }\end{array}$ \\
\hline & Ordering the product just to try it out for fun \\
\hline & $\begin{array}{l}\text { Ordering the product to try it before purchasing it from another } \\
\text { outlet }\end{array}$ \\
\hline \multirow{4}{*}{$\begin{array}{l}\text { DELIVERY } \\
\text { The items are being delivered }\end{array}$} & The customer cannot actually afford to keep the products \\
\hline & The customer regrets spending too much money \\
\hline & The product is found faster from another outlet \\
\hline & The product is found for a cheaper price at another outlet \\
\hline \multirow{3}{*}{$\begin{array}{l}\text { ARRIVAL } \\
\text { The items arrive at home or the post office } \\
\text { etc. }\end{array}$} & The customer cannot exceed their pre-defined budged \\
\hline & The customer regrets spending too much money \\
\hline & The need for the product has faded away \\
\hline \multirow{8}{*}{$\begin{array}{l}\text { SEEING, TOUCHING AND FEELING } \\
\text { The first glance at the items }\end{array}$} & An unanticipated negative feature \\
\hline & The material differs from what was expected \\
\hline & The hue differs from what was expected \\
\hline & Misleading product description \\
\hline & Misleading product pictures \\
\hline & The size of the product is too big or too small \\
\hline & The wrong product has been delivered \\
\hline & The product has defects \\
\hline & The customer perceives that the product does not fit correctly \\
\hline
\end{tabular}




\begin{tabular}{|l|l|}
\hline EXPERIMENTING & The product is not the customer's style \\
\cline { 2 - 2 } The items are tried & The product does not feel right \\
\cline { 2 - 2 } & The product has defects \\
\hline $\begin{array}{l}\text { USAGE } \\
\text { The items are being used }\end{array}$ & The product has defects \\
\hline
\end{tabular}


Table 2. Categories of online returning behaviour.

\begin{tabular}{|c|c|c|}
\hline $\begin{array}{l}\text { REASON FOR } \\
\text { RETURNING }\end{array}$ & $\begin{array}{l}\text { CATEGORY OF ONLINE } \\
\text { RETURNING } \\
\text { BEHAVIOUR }\end{array}$ & DESCRIPTION \\
\hline Product has defects & RECLAMATION DRIVEN & $\begin{array}{l}\text { Consumers return items due to the product having } \\
\text { defects, e.g. bad sewing or inappropriate materials. }\end{array}$ \\
\hline $\begin{array}{l}\text { The wrong product has } \\
\text { been delivered }\end{array}$ & $\begin{array}{l}\text { ORDER FULFILMENT } \\
\text { DRIVEN }\end{array}$ & $\begin{array}{l}\text { The wrong product has been delivered, e.g. wrong } \\
\text { colour, size or item. }\end{array}$ \\
\hline $\begin{array}{l}\text { The product is found } \\
\text { faster from another } \\
\text { outlet }\end{array}$ & \multirow{2}{*}{ COMPETITION DRIVEN } & \multirow{2}{*}{$\begin{array}{l}\text { The customer finds the same product faster or } \\
\text { cheaper from another outlet while waiting for the } \\
\text { order to be delivered. }\end{array}$} \\
\hline $\begin{array}{l}\text { The product is found for } \\
\text { a cheaper price from } \\
\text { another outlet }\end{array}$ & & \\
\hline $\begin{array}{l}\text { An unanticipated } \\
\text { negative feature }\end{array}$ & \multirow{5}{*}{$\begin{array}{l}\text { DISCONFIRMATION } \\
\text { DRIVEN }\end{array}$} & \multirow{5}{*}{$\begin{array}{l}\text { The product does not meet the expectations of the } \\
\text { customer that have been created when ordering the } \\
\text { product, e.g. the material is not what the customer } \\
\text { anticipated or expected or the product has some } \\
\text { negative feature that was not visible in the product } \\
\text { pictures, e.g. a rip or tear etc. }\end{array}$} \\
\hline $\begin{array}{l}\text { The material differs } \\
\text { from what was } \\
\text { expected }\end{array}$ & & \\
\hline $\begin{array}{l}\text { A different hue than } \\
\text { expected }\end{array}$ & & \\
\hline $\begin{array}{l}\text { Misleading product } \\
\text { description }\end{array}$ & & \\
\hline $\begin{array}{l}\text { Misleading product } \\
\text { pictures }\end{array}$ & & \\
\hline $\begin{array}{l}\text { The size of the product } \\
\text { is too big or too small }\end{array}$ & SIZE CHART DRIVEN & $\begin{array}{l}\text { The size of the product is not right even though the } \\
\text { customer ordered exactly his or her size. }\end{array}$ \\
\hline $\begin{array}{l}\text { The customer's } \\
\text { perception of the fit is } \\
\text { not right }\end{array}$ & \multirow{3}{*}{ FEELING DRIVEN } & \multirow{3}{*}{$\begin{array}{l}\text { For some reason, the customer does not feel 'right' } \\
\text { when wearing the product. }\end{array}$} \\
\hline $\begin{array}{l}\text { The product does not } \\
\text { match the customer's } \\
\text { style }\end{array}$ & & \\
\hline $\begin{array}{l}\text { The feeling of the } \\
\text { product is not right }\end{array}$ & & \\
\hline $\begin{array}{l}\text { The customer cannot } \\
\text { afford to keep the } \\
\text { products }\end{array}$ & \multirow{2}{*}{$\begin{array}{l}\text { MONEY SHORTAGE } \\
\text { DRIVEN }\end{array}$} & \multirow{2}{*}{$\begin{array}{l}\text { The customer does not eventually have the money to } \\
\text { keep all the ordered products or he/she is now willing } \\
\text { to spend that much money on the ordered products. }\end{array}$} \\
\hline $\begin{array}{l}\text { The customer cannot } \\
\text { exceed their pre- }\end{array}$ & & \\
\hline
\end{tabular}




\begin{tabular}{|c|c|c|}
\hline defined budged & & \\
\hline $\begin{array}{l}\text { The customer regrets } \\
\text { spending too much } \\
\text { money }\end{array}$ & & \\
\hline $\begin{array}{l}\text { The customer's need } \\
\text { for the product has } \\
\text { faded away }\end{array}$ & FADED NEED DRIVEN & $\begin{array}{l}\text { At the time of the product delivery, the customer } \\
\text { realizes that he/she does not actually need the } \\
\text { ordered product after all. }\end{array}$ \\
\hline $\begin{array}{l}\text { Ordering many sizes of } \\
\text { the same product with } \\
\text { the intention to keep } \\
\text { only one }\end{array}$ & \multirow{3}{*}{$\begin{array}{l}\text { BENEFIT } \\
\text { MAXIMIZATION DRIVEN }\end{array}$} & \multirow{3}{*}{$\begin{array}{l}\text { The customer orders multiple products with the } \\
\text { intention to keep only one or a few of them. }\end{array}$} \\
\hline $\begin{array}{l}\text { Ordering the same } \\
\text { product in many } \\
\text { different colours with } \\
\text { the intention to keep } \\
\text { only one }\end{array}$ & & \\
\hline $\begin{array}{l}\text { Ordering alternative } \\
\text { products for the same } \\
\text { need with the intention } \\
\text { not to keep all of them }\end{array}$ & & \\
\hline $\begin{array}{l}\text { Ordering the product to } \\
\text { just try it out for fun }\end{array}$ & \multirow{2}{*}{$\begin{array}{l}\text { JUST TRYING OUT } \\
\text { DRIVEN }\end{array}$} & \multirow{2}{*}{$\begin{array}{l}\text { The customer orders products with no intention to } \\
\text { keep any of them. }\end{array}$} \\
\hline $\begin{array}{l}\text { Ordering the product to } \\
\text { try it before purchasing } \\
\text { it from another outlet }\end{array}$ & & \\
\hline
\end{tabular}


Table 3. Unplanned and planned online returning behaviour.

\begin{tabular}{r|c|c|}
\multicolumn{1}{c}{} & \multicolumn{1}{c}{$\begin{array}{c}\text { PLANNED } \\
\text { RETURNING } \\
\text { BEHAVIOR }\end{array}$} & $\begin{array}{c}\text { UNPLANNED } \\
\text { RETURNING } \\
\text { BEHAVIOR }\end{array}$ \\
\cline { 2 - 3 } $\begin{array}{r}\text { CONSUMER- } \\
\text { INITIATED }\end{array}$ & $\begin{array}{c}\text { Benefit maximization driven } \\
\text { Just trying out driven } \\
\text { Money shortage driven }\end{array}$ & $\begin{array}{c}\text { Money shortage driven } \\
\text { Feeling driven }\end{array}$ \\
\cline { 2 - 3 } OTHER- & & $\begin{array}{c}\text { Competition driven } \\
\text { Disconfirmation driven } \\
\text { Order fulfilment driven } \\
\text { Faded need driven } \\
\text { Size chart driven } \\
\text { Reclamation driven }\end{array}$ \\
\hline
\end{tabular}


Table 4. Managerial implications.

\begin{tabular}{|c|c|}
\hline $\begin{array}{l}\text { Type of returning } \\
\text { behaviour }\end{array}$ & Managerial implications \\
\hline Reclamation driven & $\begin{array}{l}\text { - Executive emphasis on product quality } \\
\text { - Supplier audits }\end{array}$ \\
\hline $\begin{array}{l}\text { Order fulfilment } \\
\text { driven }\end{array}$ & $\begin{array}{l}\text { - Executive emphasis on delivery and order fulfilment process quality } \\
\text { - Analysis of delivery errors } \\
\text { - Incentives for error-free deliveries }\end{array}$ \\
\hline Competition driven & $\begin{array}{l}\text { - Prioritizing faster delivery times } \\
\text { - Increasing service level through more effective and efficient supply chain } \\
\text { management and vendor-managed inventories } \\
\text { - Building price guarantee schemes }\end{array}$ \\
\hline $\begin{array}{l}\text { Disconfirmation } \\
\text { driven }\end{array}$ & $\begin{array}{l}\text { - Improving the quality of the information one the company's web site } \\
\text { - Providing high-quality product images from multiple perspectives } \\
\text { - Neutral, informative product descriptions } \\
\text { - Using peers as models }\end{array}$ \\
\hline Size chart driven & $\begin{array}{l}\text { - Clear, informative size charts for each product } \\
\text { - Standardized sizing } \\
\text { - } \text { Allowing customers to comment on the size of the product e.g. on the } \\
\text { - Suggesting suitable sizes on the basis of previous purchases }\end{array}$ \\
\hline Feeling driven & $\begin{array}{l}\text { - Using different kinds of models in the product images } \\
\text { - Using peers as models } \\
\text { - Images with a } 360 \text { degree view } \\
\text { - Linking products to social media pictures with other consumers or } \\
\text { celebrities wearing the fashion item }\end{array}$ \\
\hline $\begin{array}{l}\text { Money shortage } \\
\text { driven }\end{array}$ & $\begin{array}{l}\text { - Extending credit time } \\
\text { - Possibility to pay in instalments }\end{array}$ \\
\hline Faded need driven & - Faster delivery processes \\
\hline $\begin{array}{l}\text { Benefit maximization } \\
\text { driven }\end{array}$ & $\begin{array}{l}\text { - Identifying when multiple items of the same product are ordered; } \\
\text { suggesting the right size according to previous purchases } \\
\text { - } \quad \text { Rewarding customers after a certain number of orders without any returns } \\
\text { - Clear, informative size charts for each product }\end{array}$ \\
\hline Just trying out driven & - Rewarding customers after a certain number of orders without any returns \\
\hline
\end{tabular}


Figure 1. Categories of online returning behaviour.

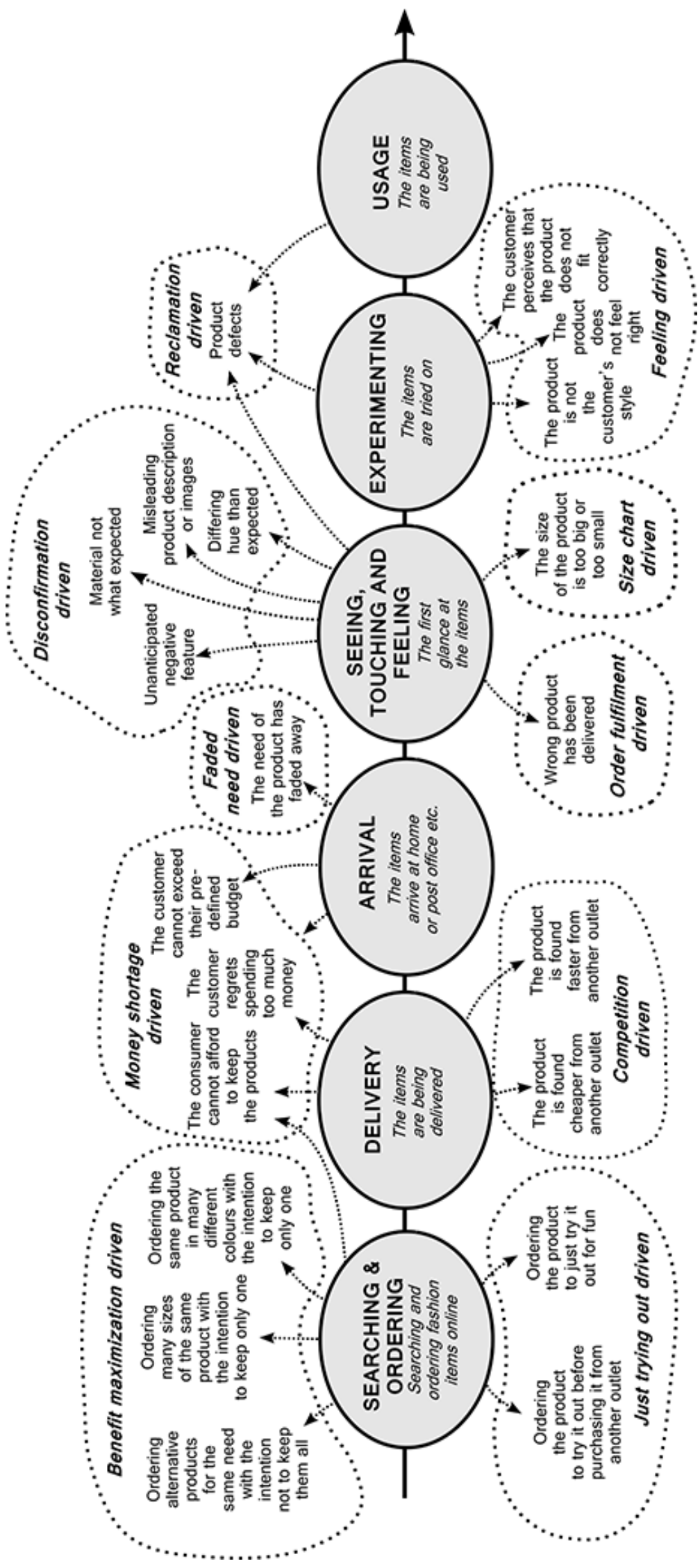

